Article

\title{
Evaluating the Authenticity of Naxi Music in Three Stages from the Perspective of Naxi Musicians: An Application of Lacan's Mirror Stage Theory
}

\author{
Dawei Li (1) and Shangyi Zhou *
}

check for updates

Citation: Li, D.; Zhou, S. Evaluating the Authenticity of Naxi Music in Three Stages from the Perspective of Naxi Musicians: An Application of Lacan's Mirror Stage Theory. Sustainability 2021, 13, 3720. https://doi.org/10.3390/su13073720

Academic Editor: Tsung Hung Lee

Received: 2 February 2021

Accepted: 23 March 2021

Published: 26 March 2021

Publisher's Note: MDPI stays neutral with regard to jurisdictional claims in published maps and institutional affiliations.

Copyright: (c) 2021 by the authors. Licensee MDPI, Basel, Switzerland. This article is an open access article distributed under the terms and conditions of the Creative Commons Attribution (CC BY) license (https:/ / creativecommons.org/licenses/by/ $4.0 /)$.
School of Geography, Faculty of Geographical Science, Beijing Normal University, Beijing 100875, China; 201831051024@mail.bnu.edu.cn

* Correspondence: shangyizhou@bnu.edu.cn

\begin{abstract}
How do people evaluate the transformation of a local music scene under tourism? Using Jacques Lacan's mirror stage theory, Manuel Castells' identity theory and Erik Cohen's authentication theory, we build a framework to judge the authenticity of Naxi music in Lijiang, China, based on interviews, literature analysis and performance analysis. The conclusions are as follows. First, there are significant differences in authenticity among the three stages of Naxi music, as defined by Lacan's theory. Second, we modify Erik Cohen's authentication concept from the perspective of Lacan and read the spirit of persistence and innovation as "hot" authentication in the postmirror stage. Naxi musicians have clear project identity, as defined by Manuel Castells. Project identity means that they do not follow the mirror image of tourists blindly and pay attention to music and their own development. This research contributes to the sustainable development of intangible cultural heritage in tourism.
\end{abstract}

Keywords: authenticity of local music; identity; tourism; Lijiang Town; mirror stage theory

\section{Introduction}

The authenticity of music performance has caused a heated debate between music experts and performers. In 2004, a lawsuit in Lijiang, China, attracted nationwide attention. This lawsuit was brought between the Lijiang Dayan Naxi Music Association and Mr. Wu, an expert on the folk music of Yunnan Province. One of the focuses of their dispute was whether the music played by the Dayan Naxi Music Association in the tourism market is authentic Naxi music. Ultimately, the Association won the lawsuit. The lawsuit has been subject to intense discussion, and one of the key points is striking. Mr. Ma, a lawyer for the Dayan Ancient Music Association, believes that experts do not have the right to authenticate local culture. Although they have not gone to court over questions of authenticity, many tourist destinations have been criticized for commercialization.

Since the launch of the reform and opening policies of the 1980s, a large and diverse tourism industry has emerged in the People's Republic of China (PRC). Many ethnic minority areas (shaoshu minzu diqu) in the PRC have developed tourism [1]. Yunnan, which is located in Southwest China, is such an area, and the provincial government identifies tourism as a "pillar industry". Yunnan has twenty-five officially recognized ethnic minorities, which makes it one of the most culturally diverse regions in the world. This cultural diversity, coupled with Yunnan's spectacular mountainous topography, attracts millions of tourists from China and abroad each year. Lijiang, the major center of the Naxi people, was the first place in Yunnan to be listed as a UNESCO World Heritage Site (WHS). The cultural heritage of Naxi music is one of the area's main tourism resources. It has found more commercial performance opportunities in a more open cultural environment.

However, the commercialization of tourist destinations that rely heavily upon cultural heritage has also caused concern among some members of the public and scholars [2,3]. 
Writing in the early 1970s, Greenwood pointed out that the commercialization of tourism tends to lead to complex and even acrimonious relationships at the tourist destination site [4]. Sustainable tourism is an important means by which local governments and residents can promote, enrich and protect local cultural heritage [5-7]. Therefore, an urgent task that facilitates the development of intangible cultural heritage as a sustainable tourism resource has been strongly advised [8].

In this paper, we examine the changes in ancient Naxi music before/after Lijiang became a popular tourist destination. We chose to examine ancient Naxi music (Naxi guyue) because it can reveal the contradictions between tourism development and cultural heritage protection that are also relevant to the sustainable tourism of many other tourist destinations in China [9,10].

Evaluating the tourism impact on ancient Naxi music is a key task for sustainable tourism in Lijiang. The UNESCO World Heritage and Sustainable Tourism Programme has five objectives. One of them is to foster an understanding and appreciation of the concept of the outstanding universal value of cultural heritage. It also addresses the responsibility and empowerment of local communities toward maintaining heritage properties and the sustainable management of tourism [11]. In this regard, the vitality of culture lies in its responsibility, communication and transmissibility [12].

Authenticity is a key concept in evaluating local heritage culture. It can be used to evaluate not only the objective authenticity of the landscape or scene of the tourism destination but also whether the tourists' perception of the tourism is positive, and the evaluation results change with time $[13,14]$. Simply put, authenticity is what makes one place distinct from another and the measure by which people judge the changes over time within a local culture $[15,16]$. If tourism development results in the local culture becoming the same as that of other places through standardized and commercialized tourism products/services, it will reduce cultural diversity [17].

How can the sustainable development of culture be understood from the perspective of authenticity? Most academic research studies authenticity from the perspective of tourists [18,19], local visitors [20,21] and the government [22]. Some scholars have noted that when evaluating the development of intangible cultural heritage from the perspective of tourists and the government, it is easy to ignore the rights of cultural heritage holders [22]. Although some articles address the attitude or value of the local performers [23], some authors are also worried that it is difficult to determine the evaluation criteria for empowering local performers and preventing the tourism commercialization of intangible cultural heritage [24]. Furthermore, the relationship between values of local performers and specific cultural performance symbols in different stages has rarely been shown. Butler noted that in the development of tourism, the cultural identity of local residents at tourist destinations changes over time [25]. Local people must re-examine their cultural heritage in light of tourism development and gradually establish self-confidence in their own culture [26]. Evaluating authenticity from the perspective of local culture carriers is also an urgent task [27]. This task is conducive to understanding the function and meaning of cultural symbols to local people, and then to understanding the authenticity of culture [28]. In doing so, we hope to provide a new framework for evaluating the cultural heritage development of tourist destinations from the perspective of the carriers of local culture.

The analysis structure of this paper is divided into the following three steps. First, this paper uses Lacan's mirror stage theory to discuss the various stages of tourism development and Naxi music preservation in Lijiang. Second, it applies Castells' identity theory to describe the characteristics of Naxi musicians' attitudes at the different stages. Finally, we modify Cohen's concepts of "cool" and "hot" authentication through Lacan's mirror stage theory to evaluate the authenticity of Naxi music. We use these three critical methods to analyze the cultural vitality of Naxi music at different stages of tourism development. This paper aims to understand the changes in authenticity of Naxi music among different periods. Under the impetus of internal and external powers, Naxi musicians transition from passivity to self-innovation, thus exhibiting "hot" authenticity. 


\section{Literature Review}

\subsection{Types of Authenticity}

There are three types of authenticity in tourist destinations, especially as defined from the perspective of tourists: objective authenticity, constructed authenticity and existential authenticity [13]. MacCannell, who discusses objective authenticity, suggests that commercialization will undermine the authenticity of a place and the real interpersonal relationships of local people because the culture on the "stage" is not as real as the cultural backstage [29]. Cohen believes that authenticity is constructed through people's views, beliefs, perspectives and powers and that authenticity is not completely objective [30]. Constructive authenticity refers to social construction. Existential authenticity refers to authenticity as the essence of being human, that is, the surfaces of things vary widely and change endlessly; the only unchanged thing is our common nature of perceiving others [31].

To more adequately examine the topic of authenticity, we must consider the changes in the relationship between locals and tourists [32-34]. For local residents in tourist destinations, authenticity has always been a negotiation between themselves and tourists [35]. Over time, however, the context of negotiation changes. For instance, in the early stages of tourism development, local residents attempt to make tourists feel welcome and experience local characteristics [36]. As time passes, however, tourists have fewer opportunities to interact with "real family space" [37]. With the increase in the number of tourists, local residents will use deception as a form of resistance and hence give tourists a false sense of authenticity [38].

\subsection{Lacan's Mirror Stage Theory}

In this paper, we argue that Lacan's mirror stage theory can reveal insights into the relationship between locals and tourists. More specifically, we apply mirror stage theory to examine the relationship between Naxi musicians and tourists. Mirror stage theory is used to divide the development stages of Naxi music in Lijiang in relation to tourism development. On this basis, we then seek to establish an evaluation framework for local cultural heritage preservation and development.

Lacan explained mirror stage theory by referring to the psychological development of the human infant-that is, the self-awareness of an eight- to sixteen-month-old baby when he or she looks in a mirror. When the baby looks in a mirror, he or she realizes that he or she is both a self (broken body) and another whole being [39]. The complete being will be confused with the self, and the baby will recognize the image in the mirror as himself or herself. In addition, the complete image will affect the development of the baby in the future. Lacan calls this transformation "alienation". Lacan believes that the mirror stage marks the emergence of a split subject-that is, someone who becomes a person who has both an internal and an external self. The mirror stage causes the subject to gradually separate from itself [40]. Lacan implies that the mirror stage represents the genesis of the self and self-consciousness in the human mind [41]. By extension, Lacan also believes that mirror stage theory explains the nature of the relationship between subjects and society [42]; that is, if people want to realize their free development of self-spirit, they should extricate themselves from the limited framework given by society and reach a state of existential authenticity [43].

Lacan's mirror stage theory has been widely used in social science research; however, it has not received much attention in the development of local cultural heritage subjects. Some find that his ideas are presented in a way that is somewhat perplexing and difficult to comprehend [44]. However, it is undeniable that Lacan's mirror stage theory is still very useful in psychological analysis [45]. Moreover, Lacan's interest in the philosophy of the mind helped establish a connection between phenomenology and psychoanalysis [42].

\subsection{Modification of the Concepts of "Cool" and "Hot" Authentication by Mirror Stage Theory}

We argue here that Lacan's mirror stage theory can be used to modify the implications of Cohen and Cohen's notion of "hot" and "cool" authentication [46]. "Cool" authentication 
is based on the judgement of expert or scientific knowledge. However, it may detach the content of authentication from people's daily life and even lead to cultural rigidity or stagnation. For example, the Maori in New Zealand make crafts as souvenirs. In selling crafts, they seek to have the national authority label their crafts as indigenous products. However, there are many characteristics and traditions in Maori arts. Therefore, official certification is not conducive to receiving the full inheritance of Maori arts [47]. Another example is the traditional houses in Hongcun Village, China. To maintain the authenticity of the ancient village, local residents have no right to repair their own houses. This has caused some local residents to move out of the village due to poor living conditions [48]. "Hot" authentication is based on the belief and enthusiasm of the local subject [46]. For example, Chhabra, Healy and Sills found that Scots living in the United States, Canada and other places reconstructed the Modern Highland Games [49]. This staged festival creation is far from its cultural origin in space and time, and many participants do not even have personal experience with Scotland. Nonetheless, the revival of the traditional Scottish sporting contest promotes nostalgia for the past and strengthens connections with present culture. Therefore, people still attach a strong sense of authenticity to this event. Some scholars have criticized Cohen's point of view and suggested that the method of authentication needs further discussion. For instance, Mkono believes that if expert words are used as the basis for "cool" authentication, then "authenticity" can be reduced to a matter of "authority" [50]. Therefore, we believe that authenticity authentication should begin from the mirror image relationship between local people and tourists and judge whether local people achieve the promotion of the freedom of the human spirit proposed by Lacan.

Our definitions of these two types of authentication can be used to emphasize the reflection of tourists and locals. When tourists and local people encounter each other in a tourist destination, they play the part of mutual "mirrors". We are not the first to suggest this possibility. For instance, Knudsen, Rickly and Vidon used Lacan's theory to argue that authenticity is an illusion perceived by tourists who want to find an experience that does not exist in their own body of alienation [51]. The authenticity perceived by tourists is existential authenticity. Wijngaarden even posited tourist representation as a mirror to reflect in performance what the tourists desire [52].

In this paper, we argue that it is necessary for us to add two stages: one before and one after the mirror stage. If we want to analyze problems in tourism from the perspective of constructed authenticity, we must understand the nature of authenticity before the encounter between tourists and tourist destinations. Thus, we must examine the premirror stage before the mirror stage. If we want to analyze those phenomena from the perspective of existential authenticity, then we must understand whether there is an improvement in the social conditions and human relationships between tourists and locals after the mirror stage. For this reason, we add the postmirror stage after the mirror stage.

\subsection{Description of Cultural Identity from Castells}

To analyze authenticity, we cannot avoid the concept of cultural identity. Giddens believes that identity is the source of meaning for an actor but that it is also constructed through the individualized process of the actor [53]. Castells defines "meaning" as the symbolic identification of the behavioral purpose of actors. According to the difference between the form and origin of identity, Castells divides identity into legitimizing identity, resistance identity and project identity [54]. Of these, legitimizing identity refers to the identity defined by the dominant social system (such as laws). Resistance identity is the identity generated by actors who are in positions/conditions that are devalued and/or stigmatized by the logic of domination. Project identity comes from those who have been stimulated in terms of their resistance identity and want to establish a new social position. Etzioni pointed out that resistance identity may be the most important constructive type of identity in society because it is related to the formation of a community [55]. Especially in a network society, no type of identity is essential or invariable, and all those types of identity must be placed in a historical context to understand the foundation of their formation [56]. 
In short, we wish to observe whether individuals can gradually feel liberated from the "alienation" they experience during the process of pursuing authenticity. This kind of "relief" is akin to the anti-alienation advocated by Lacan. On this basis, we find that the main feature of the postmirror stage is that the Naxi musicians are opposed to the image of alienation during the performance process. In this way, the authenticity of self and other is achieved within a mutual mirror.

\section{Research Area and Methodology}

\subsection{Research Area}

Lijiang is a prefectural-level city located in northwestern Yunnan Province, the People's Republic of China (Figure 1). The main urban center is the Lijiang Ancient Town (Lijiang guzhen), which was listed as a World Cultural Heritage Site in 1997. Lijiang is populated by a number of ethnic groups including the Naxi, Han, Lisu, Yi and Mosuo. The Naxi are the largest ethnic group. There are two reasons for choosing Lijiang as the research site.

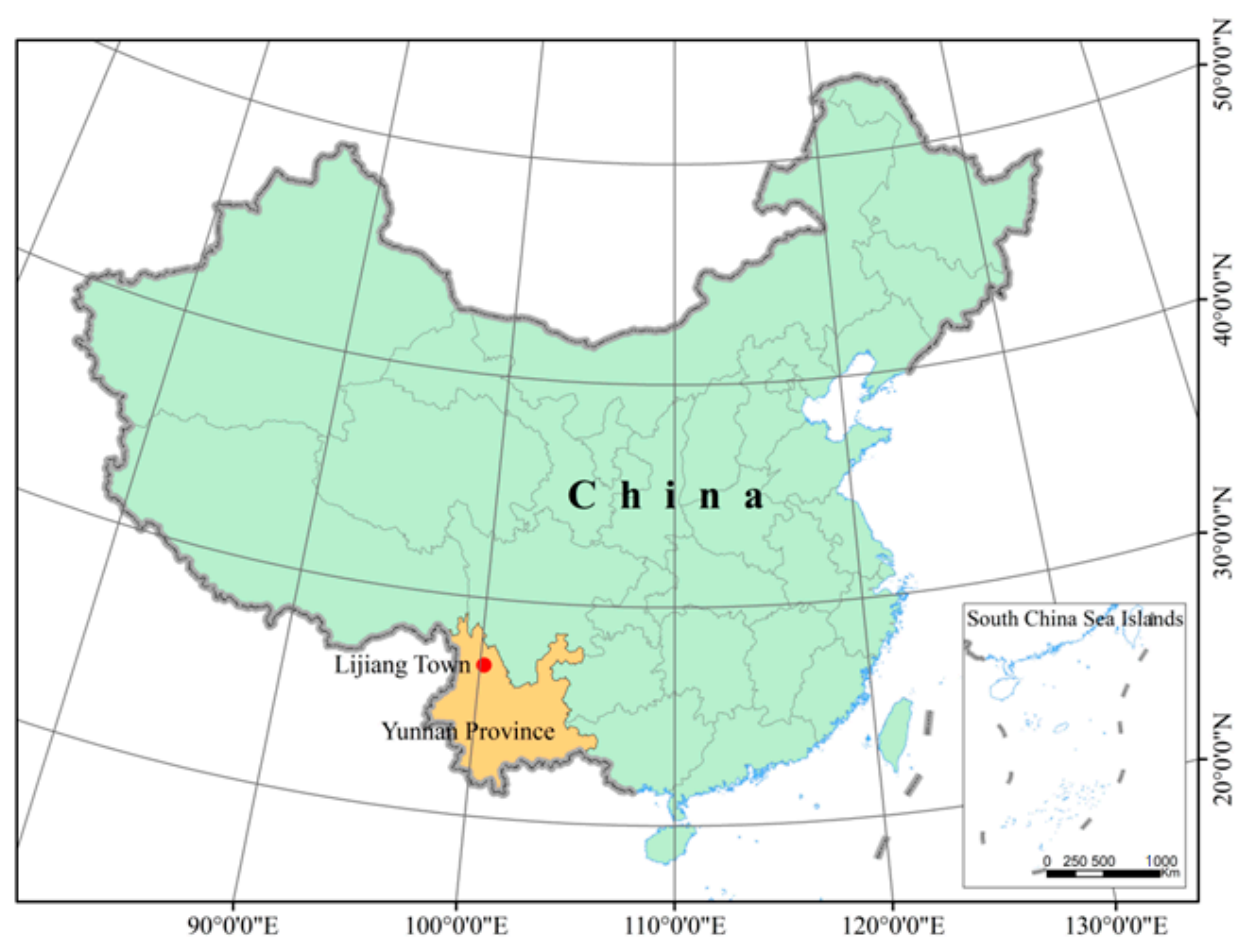

Figure 1. The location of Lijiang Town.

First, the development of tourism in Lijiang is typical. Tourism in Lijiang first began to be actively promoted and developed when it was listed by the Chinese government as a "historical and cultural city" (lishi he wenhua guzhen) of China in 1986. Tourism prospered even more after Lijiang Town was named a World Heritage Site (WHS) in December 1997. Data from the official website of the Lijiang municipal government show that the number of tourists in 1990 was only 96,000. Subsequently, the number of tourists increased to two million in 1998. The increased numbers of tourists created a large audience for Naxi music. The tickets for the performances of the Dayan Classical Music Association have been described as "difficult to obtain", which shows the high degree of tourists' enthusiasm during that early period of tourism development.

Second, Naxi music is both ethnic and local. Not every place in China has its own unique music. A major feature of Naxi music is that it is both diverse and varied. Therefore, it is very conducive to studies concerning authenticity and sustainability. The major components of Naxi music are Baisha music, Dongjing music and Dongba music. Naxi music has undergone many transformations over time; however, it has also maintained continuity 
over a long historical period. Naxi music traditions were greatly influenced by the Han culture. At the same time, the different types of Naxi music interacted with and were inspired by each other. Hence, the cultural vitality embodied in Naxi music is worth studying. Dongjing and Baisha music are the most common types of music performed for tourists in Lijiang. In this regard, we examine the performers of Baisha and Dongjing music.

\subsection{Research Framework and Methods}

The data collected for this study derive from field research, interviews and textual analysis. In May 2015, September 2017 and September 2020, the authors observed Naxi music performances in Lijiang and conducted semistructured interviews with Naxi music performers and tourists (Table 1). The interviews were mainly conducted in Chinese. The main purpose of the interviews was to determine the emotional attitudes and changes of Naxi musicians and tourists towards Naxi music to analyze the relationship between Naxi musicians and tourists. We also analyzed the history of tourism in Lijiang by searching and summarizing materials related to Naxi music in books, newspapers and academic papers.

Table 1. The details of the interview participants.

\begin{tabular}{|c|c|c|c|c|c|c|}
\hline Serial Number & $\begin{array}{l}\text { Interview } \\
\text { Participants }\end{array}$ & Gender & Age & $\begin{array}{l}\text { Average } \\
\text { Interview } \\
\text { Length }\end{array}$ & Interview Focus & Interview Time \\
\hline N1-16 & Naxi musicians & $\begin{array}{l}\text { Male } \\
87.5 \% \\
\text { Female } \\
12.5 \%\end{array}$ & $\begin{array}{c}91-1006.25 \% \\
81-9025 \% \\
71-8025 \% \\
61-7012.5 \% \\
51-6012.5 \% \\
41-5012.5 \% \\
31-406.25 \%\end{array}$ & $60 \mathrm{~min}$ & $\begin{array}{l}\text { The history of Naxi music } \\
\text { Methods of inheritance of } \\
\text { Naxi music } \\
\text { The innovative aspects of } \\
\text { Naxi music } \\
\text { Changes in tourism } \\
\text { performance }\end{array}$ & $\begin{array}{l}\text { May } 2015 \text { and } \\
\text { September } 2020\end{array}$ \\
\hline L1-12 & Local residents & $\begin{array}{l}\text { Male } 60 \% \\
\text { Female } \\
40 \%\end{array}$ & $\begin{array}{l}61-7025 \% \\
51-6025 \% \\
41-5025 \% \\
31-4025 \%\end{array}$ & $20 \mathrm{~min}$ & $\begin{array}{c}\text { Cognition and attitude to } \\
\text { Naxi music } \\
\text { The functional connection } \\
\text { between Naxi music and } \\
\text { daily life }\end{array}$ & $\begin{array}{c}\text { September } 2017 \text { and } \\
\text { September } 2020\end{array}$ \\
\hline $\mathrm{T} 1-20$ & Tourists & $\begin{array}{l}\text { Male } 50 \% \\
\text { Female } \\
50 \%\end{array}$ & $\begin{array}{l}51-6035 \% \\
41-5035 \% \\
31-4020 \% \\
21-3010 \%\end{array}$ & $20 \mathrm{~min}$ & $\begin{array}{l}\text { The feeling of watching a } \\
\text { Naxi music performance } \\
\text { Advice for the } \\
\text { development of } \\
\text { Naxi music }\end{array}$ & $\begin{array}{c}\text { May 2015, } \\
\text { September } 2017 \text { and } \\
\text { September } 2020\end{array}$ \\
\hline G1-2 & Government staff & $\begin{array}{l}\text { Female } \\
100 \%\end{array}$ & $\begin{array}{l}51-6050 \% \\
31-4050 \%\end{array}$ & $60 \mathrm{~min}$ & $\begin{array}{l}\text { The development and } \\
\text { transformation of Naxi } \\
\text { music in tourism } \\
\text { Methods of managing } \\
\text { Naxi music performances }\end{array}$ & September 2020 \\
\hline
\end{tabular}

This study refers to the research of several scholars to describe the dimensions of music such as instrumental form, musical style, lyrics, language, accent, instruments and melody [57]. Some scholars believe that abstract spiritual culture is intangible and cannot be directly linked to specific musical forms [58]. Nevertheless, there are some musical features that are regarded as local or national cultural symbols with which people identify emotionally and spiritually [59]. We propose identifying those features below.

The first step is as follows. Based on the previous research and against the background of global tourism, we identified three development stages of Naxi music based on Lacan's mirror stage theory. The stages are the premirror stage, the mirror stage and the postmirror stage.

The analytical framework of this study is shown in Figure 2. The framework consists of three steps.

The second step uses Castells' cultural identity theory. For this, we interviewed the Naxi music performers and confirmed their cultural identity in the three stages of Naxi music mentioned above. We interviewed fifty individuals including Naxi musicians, tourists, government staff in Lijiang and local residents. Our interviews were conducted in pubs/cafes, performance venues, the streets in the ancient part of Lijiang Town and the 
courtyards of local residents in Wenlin Village, Sanyuan Village and Changshui Village. Refer to Table 1 for the details of the interviews.

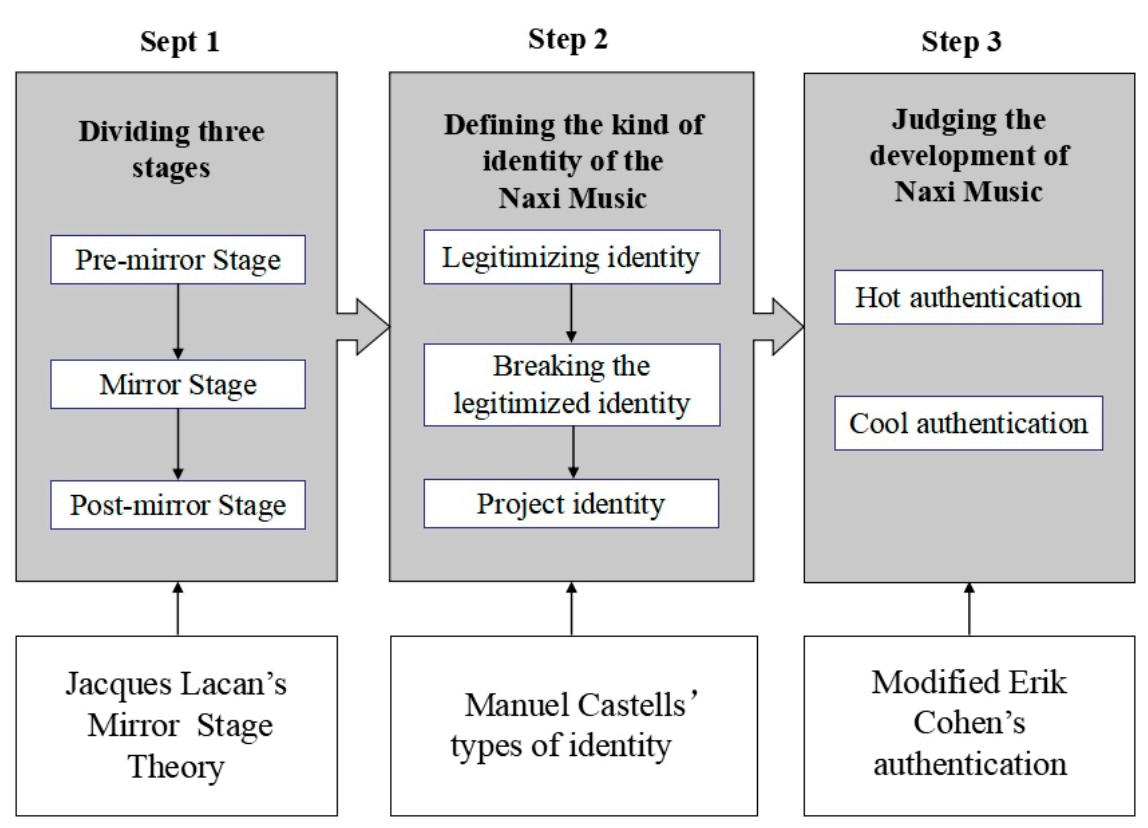

Figure 2. The research framework of this case study.

The third step is to determine whether Naxi music could be subject to the processes of "hot" or "cool" authentication in the three stages. This step constitutes the innovative feature of this research, which is to improve the definition of "cool" and "hot" authentication as proposed by Cohen. We use the modified concepts of "cool" and "hot" authentication to evaluate whether Naxi musicians have broken the mirror image of tourists and become their existential self in their music practice.

\section{Analysis of the Survey Materials}

\subsection{The Legitimizing Identity of the Premirror Stage (1950s to Mid-1980s)}

From the founding of the People's Republic of China in 1949 to the development of tourism in the 1980s and beyond, the function of Naxi music has undergone a huge change. According to the research on the history of Naxi music, in dynastic China (before the 1912 fall of the Qing Dynasty and the establishment of the Republic of China), Dongjing and Baisha music were mainly played on ceremonial occasions such as when conducting a funeral. Donging music was also played in religious ceremonies. For example, on the birthday of Wenchang (a popular deity found across China that is regarded as a heavenly counterpart to the terrestrial emperor), people would go to the temple to invite the Donging band to play music to hold a temple meeting. If a family member were sick, people would also go to the temple to play Dongjing music and hold a family meeting. After 1949, with the founding of the People's Republic of China, the performance of Dongjing music in the temple was considered to be superstitious and backward. Dongjing music gradually became separated from religious rituals and was relegated to folk bands. Dongjing music was still performed in various local folk festivals, celebrations and funeral ceremonies. However, at this time, Baisha music is no longer used in funeral ceremonies, and Baisha music has faced a crisis of inheritance from one generation to the next.

From 1967 to 1976, the decade of the Cultural Revolution, the performance of Dongjing music and Baisha music was labeled "backward" and a "feudal superstition" and prohibited. During this period, almost no one dared to learn the music, and all musicians were forced to disband. Only He Maogen in Changshui Village studied Baisha music from $\mathrm{He}$ Xidian at night and in secret, thereby preserving Baisha music. At the end of the 1970s, 
as China began to explore the policies of "reform and openness", Xuan Ke, a prominent member of the local Naxi cultural elite and a Dongjing music practitioner, reorganized the surviving folk artists-many of whom were already quite venerable and in their 70s and 80s - and they began to practice Dongjing music for entertainment.

In this period (from 1949 to 1986), although the development of music was relatively fraught, Naxi musicians and listeners chose to make certain elements of the music legal but without tourists as a mirror. The characteristics of the music during this period can be summarized in terms of seven aspects.

First, the function of the musical performances was limited. In folk activities, each piece of music corresponds to a specific function. "Xuanbai" is a step in the funeral of the Naxi people while playing two pieces of Baisha music, one of which is referred to as "Du". Dongjing music also includes some Naxi funeral music. In the funeral part of "Xuanbai", the band would play "Xiao baimei" (Little Plum Blossom). Some Donging music pieces were played on celebration days. These included birthdays, marriage days and house building days. Some of these dates may have been selected from the almanac to find auspicious times. For such events, the Dongjing music repertoire often played was "Dao chun lai" (In the Spring), "Jixiang" (Auspicious) and other beautiful movements. Baisha music does not have a celebration function; thus, more limitations are placed on the audience.

Second, the lyrics corresponded to specific folk functions. For example, the lyrics of Baisha music were mostly used to pray for peace of mind, which are also referred to as a "Requiem". Three of the eight movements of Baisha music have lyrics, and the lyrics are all in Naxi. Among those movements, there are many adjectives in the lyrics of "Stomp" (Duo cuo). This is because this movement must express the whole life of the dead. Therefore, facing different deceased people, the lyrics of "Stomp" are also different. In another movement in Baisha music, "A lili Gou jipe" (in Naxi), the lyrics are composed to appease the deceased-for example, "the deceased is going to the west, please go with peace of mind...". The lyrics of Dongjing music are mainly composed for ceremonies. For example, "Shi gongyang" (ten offerings) in Dongjing music corresponds to ten types of offerings in folk activities. After each offering, the "Shi gongyang" must be played. A slogan in the "Shi gongyang", "The original heavenly king descends to auspiciousness, only hope that mercy descends to the human world", reflects the desire to pray for peace after worshipping the gods.

Third, the top-level performers of Baisha and Dongjing music were adult males who displayed great enthusiasm and innovation. The players of the Lijiang Dongjing and Baisha bands are familiar with the tunes and lyrics of their music. The inheritance of both types of music is oral. Oral teaching is characterized by the use of Gongche notation (a kind of traditional Chinese music score) (Figure 3), which cannot be recorded with modern musical notation. Players are required to memorize several backbone notes and master some basic skills between each backbone tone. These skills are an important way to express the emotions of Naxi music. The top-level musicians of Dongjing and Baisha music can improvise according to their emotional state.

Fourth, strict methods of inheritance and learning should be used. During this period, the way in which people learned music was to skillfully memorize the Gongche notation of each movement. After that, they found a musical instrument teacher and learned the unique playing skills from him. As the teacher of each instrument had his own understanding of a specific movement, students learned the unique understanding of the instrument teacher when they played. After students became proficient in playing, they could add their new perceptions of the music in different situations.

Fifth, during this period, communication between the bands was shared. As all players can add their own unique understanding in the performance of Naxi music by using Gongche notation, there are differences between good and bad in the new performance skills. For example, in some Naxi villages, many villagers regularly organize performances in public places, which is an important way to improve personal music skills. They may 
learn the advantages from each other and point out some shortcomings. The most typical example is described in the following interview:

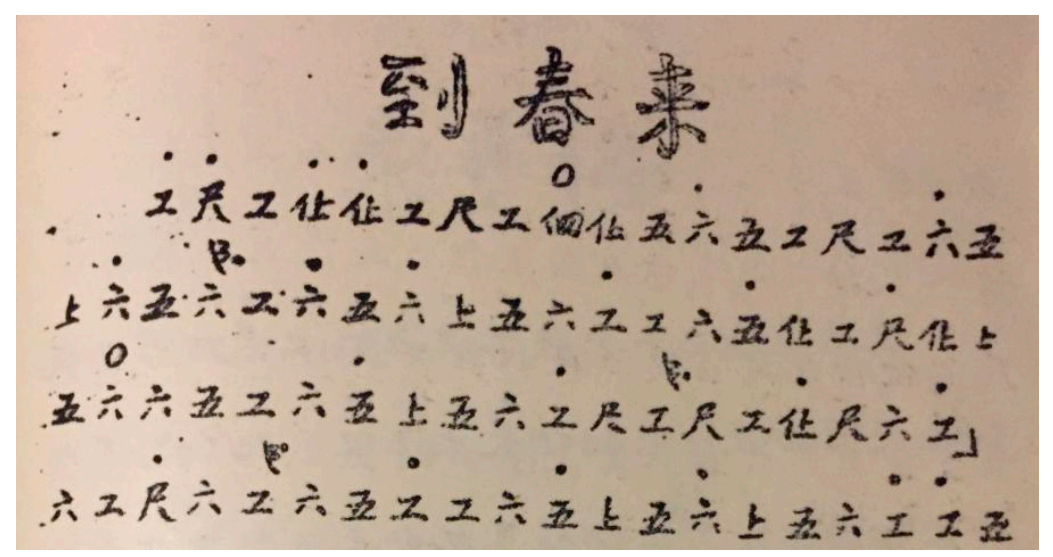

Figure 3. A sample piece of the Gongche notation of "Dao chun lai" (In the Spring). Note: This a traditional musical notation method that was popular in ancient China. It uses Chinese characters to represent musical notes. It was named after two of the Chinese characters that were used to represent musical notes—namely, “工” gong and “尺” che. The photo was taken by the author in 2020 .

"At that time, we had to go to the Naxi music associations in various villages to exchange and learn the performance skills of Dongjing music. Different bands have different innovation points. If you can learn the innovation points of different bands, your own perception of music will be greatly improved." (Naxi Musician 3, September 2020, Lijiang Wenlin Village)

Sixth, compared with innovation in performance, the types of musical instruments were relatively fixed. This concept is related to the function of music. Baisha music uses only wind and bowed instruments, not percussion instruments. This is also related to the sad and sweet emotion that Baisha music wants to reflect in the funeral ceremony. Compared with Baisha music, the obvious feature of Dongjing music is its percussion instruments, such as drums and gongs, which reflect the solemn atmosphere of Taoist music.

In summary, before the tourist wave, Lijiang Dongjing music and Baisha music were integrated into the lives of local musicians and residents. Naxi musicians regularly held Dongjing music exchange activities. In this process, their performances are not limited to playing stereotypically according to the musical notation. They can add their own marks on the Gongche notation to play. Some good performance ideas can be shared by the performers of various ancient music associations. At this time, although the environment in Lijiang is relatively closed, Naxi music is open. Naxi musicians pursue the beauty of music and resonance and harmony with others, thus showing the authenticity of the "hot" authentication of local musicians. Therefore, we believe that the authenticity constructed by Naxi musicians can pass "hot" authentication at this stage.

\subsection{The Break from Legitimizing Identity in the Mirror Stage (Mid-1980s to 2007)}

The development of tourism further stimulated the emergence of some new groups of Naxi musicians. In 1979, relevant departments of the Lijiang government encouraged some old artists to play Naxi music. As a result, activities that were centered around Naxi music gradually began to (re)appear. In the late 1970s, the performances of Dongjing music gradually entered a new period of prosperity. In the mid-1980s, the Dayan Classical Music Association was established. It was the first official association for Naxi music after the Cultural Revolution. Niu Weijiong was the manager, and Xuan Ke was the deputy manager. Later, additional Naxi music associations were established in other parts of the Lijiang region such as in Baihua, Changshui, Jinshan, Baisha, Lashi, Shigu, Judian and Wenming. In 1997, seventeen Dongjing Classical Music Associations were registered. Regarding the 
sustainability of Baisha music, the heritage practitioner He Maogen continued to encourage the inheritance of the music between family members, which is helpful for training and reducing economic disputes when musicians perform for tourists. Thus, this system of inheritance is quite different from the former method of transmission.

To satisfy the needs of tourists, changes were made in the legitimacy elements of Naxi music in the premirror stage. Some Naxi musicians held the opinion that tourism could provide a platform to showcase Naxi music, and at the same time, they could also obtain some income. The legitimacy arguments can be summarized as follows.

First, they separated music performances from folklore activities to adapt to tourists' itineraries. In the early 1980s, during the early stage of tourism development in Lijiang, there were few tourists. Xuanke and other Naxi musicians would take the initiative to recommend Naxi music to tourists in some bars at the time and organize musicians to play music for tourists. Naxi music was played once a week on average. After Lijiang Town became a national B-level open zone in 1986, the number of foreign tourists visiting Lijiang Town gradually increased. At that time, there were few hotels in Lijiang. The Lijiang Hotel was one of the better hotels in the area. Xuanke and other Naxi musicians were invited to the hotel to play for the tourists.

Second, to adapt to the tourist atmosphere, Naxi musicians gradually changed the inherent combination of musical instruments. To attract tourists, some performing bands added new instruments, such as percussion, to the performance of Baisha music. One Naxi music performer explained the following:

"Originally, the musical effect of playing with instruments was relatively quiet.

Due to changes in the playing scene, we added some percussion instruments to enhance the performance." (Naxi musician 5, May 2015, Lijiang Ancient Town)

Third, many young people's purpose and way of learning Naxi music have changed. To quickly accommodate the stage performance to the tourism context, many young people no longer recite the Gongche notation but directly read modern musical notation to play various musical instruments. The advantage of this is that a musician can quickly learn to play a certain tune; however, the disadvantage is that it is more difficult to innovate. One Naxi musician stated the following:

"I have two apprentices like this. It takes three days for one apprentice to learn a piece of Gongche notation and memorize many "additional" skills. Another apprentice only used modern musical notation to learn, and it only took just over an hour to learn a piece of music, so he quickly learned and found that learning music was very simple, and he no longer thought about further innovation." (Naxi musician 3, September 2020, Lijiang Wenlin Village)

"At that time, I really thought about how to make money every day, opening a restaurant during the day, and participating in the Dongjing music performance at night." (Naxi musician 6, September 2017, Lijiang Ancient Town)

Fourth, the movement of Naxi music performance should also be adapted to the stage. In terms of the meaning of the lyrics, many performers will choose "Bagua" (The Eight Diagrams), "Jixiang" (Auspicious), "Yuanshi" (Primitive) and other ceremonial repertoires that were originally performed in marriage and birthday celebrations. For the length of the performance, some musicians will choose the repertoire according to the audience.

Fifth, the Naxi musicians also broke the rules that only men can participate in the performance by training actresses to perform with the musicians (see Figure 4). These changes were made to cater to tourists' expectations but not to Naxi musicians and local people. They pursued the transformation of this musical art at the cost of the legitimate musical identity. As one performer explained.

"Later, many women in the village gradually began to learn Naxi music because tourists came and asked why they were all male musicians." (Naxi musician 6, May 2015, Lijiang Ancient Town) 
Sixth, to enhance the understanding of tourists, many musicians add commentary. Mr. Xuan Ke of the Dayan Ancient Music Association will add Chinese and English commentary to the ancient music performance every night. Baisha music inheritor Mr. He Lingyi will not only introduce the meaning and function of the music but he also tells the story of the inheritance of Baisha music to tourists. Many tourists are moved by the difficult inheritance process of traditional music.

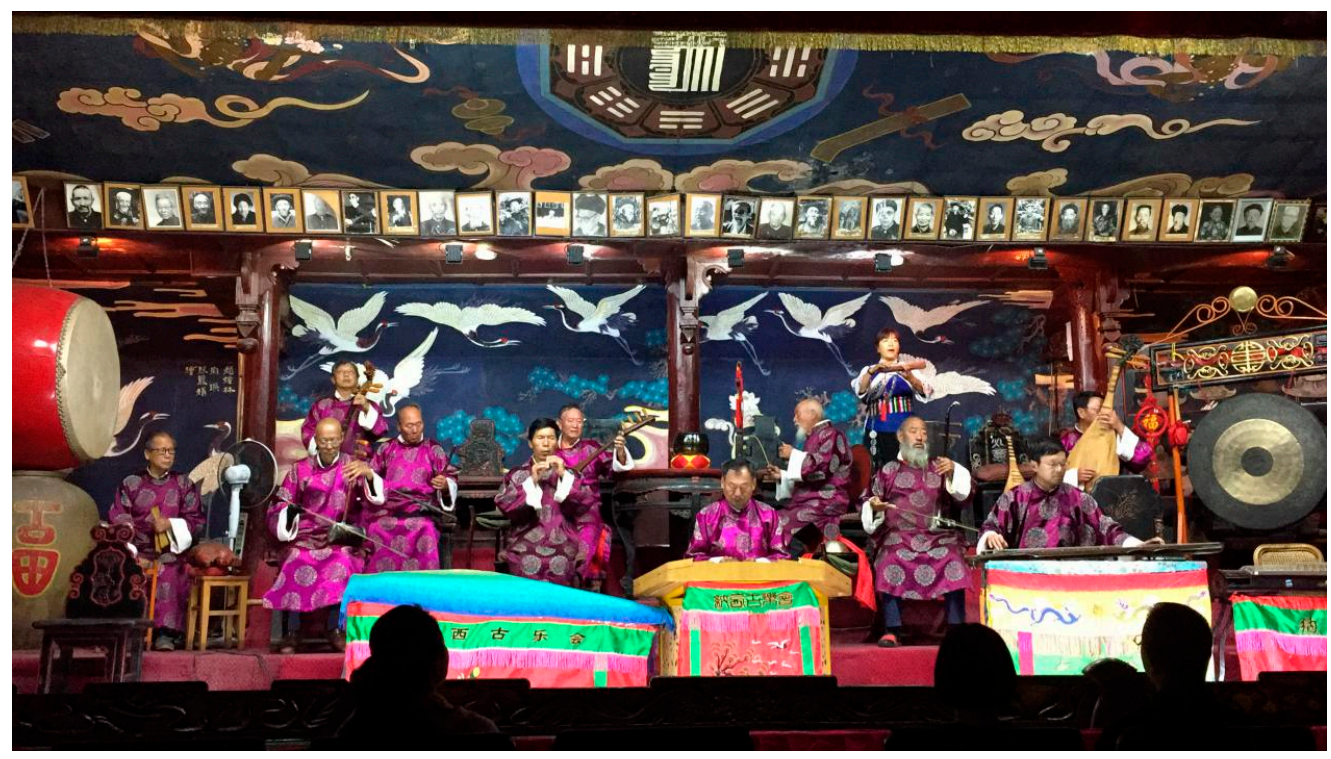

Figure 4. Naxi music performance of the Dayan Ancient Music Association. The photo was taken by the author in 2020, with the permission of the concert.

"We can gain a better understanding of Naxi music through the commentary. Additionally, I even think that the explanation is more moving than the Naxi music."(Tourist 1, May 2015, Lijiang Ancient Town)

Seventh, in addition to adding commentary, Naxi musicians have also adapted lyrics to enhance the tourists' understanding. In 1985, Xuan Ke set the poem "Langtaosha" (Waves Washing the Sand), which was written by Emperor Yu Li (937-978) of the Tang Dynasty, to the lyrics of Dongjing music (Table 2). This was because most tourists from China are familiar with Emperor Yu Li's poems. This music adaptation resonated with many Chinese tourists. The following words from the interviewees provided confirmation.

Table 2. Lang Tao Sha: a lyric of Naxi music.

\begin{tabular}{cr}
\hline Original Chinese Lyric & English Translation \\
\hline 帘外雨浔潺 & The murmur of rain could be heard \\
春意阑珊 & The smell of spring faded \\
罗含不耐五更寒 & Silk quilt cannot defend the cold at night \\
梦里不知身是客 & I was an insider that only be dreamed \\
一晌贪欢 & Peace came to me at dreaming moment \\
独自莫凭栏 & On the porch alone and looking out \\
无限江山 & Gaze motherland in the remote \\
别时客易见时难 & Break up with it easy and reunion is difficult \\
流水落花春去也 & River flow, falling flowers and spring gone together \\
天上人间 & The past was in heaven and now is on the ground \\
\hline
\end{tabular}

"My favourite piece of Dongjing music is "Langtaosha." I had never expected to hear the original song of that familiar poem in Lijiang." (Tourist 2, May 2015, Lijiang Ancient Town) 
However, this adaptation also caused another lawsuit. Due to the great success of Li Yu's poems in the tourist market, Dongba Palace, another place where Dongjing music is performed in Lijiang, also uses Li Yu's poems. The Dayan Ancient Music Association believed that the performers of Dongba Palace had infringed on copyrights and took the performers of Dongba Palace to court.

At this stage, the Naxi musicians broke with the legitimizing identity originally rooted in the locality according to the tourism situation. They resumed their performance of Naxi music after decades of prohibition and, in the new environment of "reform and openness", they made changes for the development of the music to suit the new circumstances. During this period, tourists began to express a passion for Naxi music because they could understand some of the context of Naxi music and envision the music to be authentic. However, these changes cater only to tourists' views. This development impairs the subjective vitality of the musicians. At the same time, it can be seen from the above analysis that music performance at this time contains many elements of commercial competition, and there are many nonshared, rigid and even sharp elements. The authenticity perceived by tourists in this context can be regarded as a form of "cool" authentication.

\subsection{Project Identity in the Postmirror Stage (2007 to Present)}

The major distinguishing feature of the postmirror stage is that the Naxi musicians no longer passively cater to tourists' consumption preferences. After the lawsuit between the Dayan Naxi Ancient Music Association and Chinese intangible cultural heritage protection experts in 2004, many scholars believed that the performance of Naxi music was eroded by commercialization. In addition, the tourists did not respond as enthusiastically as they had before. Some scholars believe that many of the interpretations of the Dayan Classical Music Association did not relate to objective facts. They felt that such performances might "deceive" the vast number of domestic and foreign audiences but not the scholars [60,61]. Scholars also believe that the performances by the Naxi musicians in this context always include the playing of specific movements or pieces of Naxi music every time. The result is that most parts of Naxi music are not incorporated into these regular performances and would thus be gradually forgotten. After 2006, "Yinxiang Lijiang" (Impression of Lijiang) and other external performance institutions and capital injections greatly diverted tourists who watched Naxi music performances. After 2007, the number of visitors to the Classical Music Association to listen to Naxi music was only approximately two thirds of that of the mirror stage.

In 2006, China announced the first series of national intangible cultural heritage designations, and the intangible cultural heritage designations in various regions also began to actively be declared. This also forced the Naxi musicians to rethink and reorganize their own music and adjust the development of the music. The Baisha music player He Linyi rearranged the eight movements of Baisha music and was successfully approved as a national intangible cultural heritage inheritor in 2011. During the four years from 2012 to 2015 , he organized more than ten people to perform public welfare performances in the Guanyinxia tourist attraction in Lijiang. He described his path towards inheritance as follows:

"The inheritance and development of Baisha music must be divided into two paths. One is the original inheritance of Baisha music. The other is that it can be adapted in the performance. For example, I will also add some elements of the Bai, $\mathrm{Yi}$, and Lisu (some ethnic groups of China) music melodies to the performance of Baisha music, but I will explain which other ethnic groups I have added before the performance." (Naxi musician 2, September 2020, Lijiang Changshui Village)

Facing the impact of external capital and the support of national policies, more Naxi musicians such as He Linyi gradually established a new project identity. Their project identity is characterized by adhering to their own culture, creating new Naxi music, holding their own cultural festivals and playing for self-entertainment even when there are no tourists. 
For example, very few tourists come to the Dayan Ancient Music Association to listen to Naxi music now, in sharp contrast to the popular bar street next to the Ancient Music Association. Despite this, the musicians still insist on performing every night. A Naxi musician described the situation as follows:

"We will still insist on performing the music, even if there are only five people in the audience listening to Naxi music (at the Dayan Classical Music Association) every night." (Naxi musician 6, September 2017, Lijiang Ancient Town)

"The bar next to the Dayan Classical Music Association is very noisy, but there are only a few people listening to Naxi music. Additionally, these old people still insist on performing; I admire their persistence." (Tourist 6, September 2017, Lijiang Ancient Town)

During this period, many villagers in Lijiang still spontaneously organized the performance of Dongjing and Baisha music. For example, the elderly in Wenlin Village organize playing music at the village committee every Monday and Thursday afternoon (Figure 5). Many of them began to learn Naxi music after retirement; therefore, they usually use modern musical notation. However, they learned their fingering skills from skilled musicians who are proficient in Gongche notation. Since 2012, with the support of the Lijiang Government Ancient Music Associations, more than 20 villages have taken turns performing on the stage of Heilongtan Park every Tuesday and Thursday afternoon. As the performance of these players is not very proficient, the musical teachers come to provide guidance every time.

In the process of playing, the musicians do not rigidly stick to the music. In the absence of tourists as mirrors, to improve on their performance of Naxi music, the musicians have made the following improvements.

For the musical notation, the inheritor of Dongjing music created a new form of musical notation, which corresponds to the modern numbered musical notation and Gongche notation. The advantage of this is the use of modern music notation to play the instruments and the use of Gongche notation with the lyrics to facilitate singing the songs. The music sung in this way is closer to the original Naxi style (Figure 6). Another advantage of this approach is that the performers can choose the musical notation that is more familiar to them.

In terms of musical instruments, some high-level musicians have also tried to add the Xiao (a traditional Chinese musical instrument) to Dongjing music. This is because the Xiao was used historically in Dongjing music. In addition, in a more open environment, some Dongjing musicians have transformed their instruments by incorporating modern musical instrument production technology. One disadvantage is that the former pipas (a type of lute) in the Lijiang area were vulnerable, low in volume and inaccurate in tone. To overcome these shortcomings, the Naxi musicians invited a senior technician from the Musical Instrument Factory in Suzhou to modify the pipa. First, the belly was changed from one piece of wooden board to three pieces. Second, to improve the accuracy of tone, the distance from the head to the tailpiece was shortened, and strings were changed to thicker ones. Third, to increase the volume, the sound hole (half-moon) was enlarged, and a sound post was added behind the belly (Figure 7).

In the lyrics, the Lijiang Dongjing musicians added poems that were more in line with Taoist music. Taking "Langtaosha" as an example, some musicians put Lv Dongbin's poem to the tune of the same title. Lv Dongbin was the founder of the Quanzhen School of Taoism in the Tang Dynasty. According to legend, he also made Taoist music, which was free and closer to nature. Langtaosha music is more in line with the elegant style of Taoist music as opposed to the feeling of desolation conveyed by Li Yu's poems. In addition, some Naxi musicians have sought to resume the Dongjing concerts of the late Qing Dynasty and early Ming Dynasty. They hung a portrait of god Wenchang at the performance venue and arranged instruments on stage according to the eight diagrams (eight combinations of 
three whole or broken lines formerly used in divination) (Figure 8). The performance was not only designed to entertain people but also dedicated to the gods of Taoism.

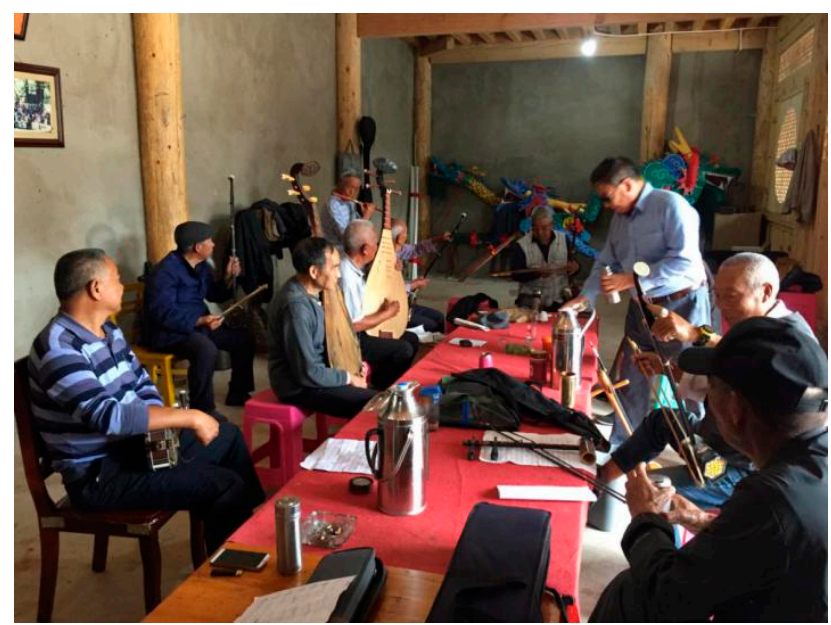

Figure 5. Elders playing Donging music at Wenlin Village. The photo was taken by the author in 2020 .

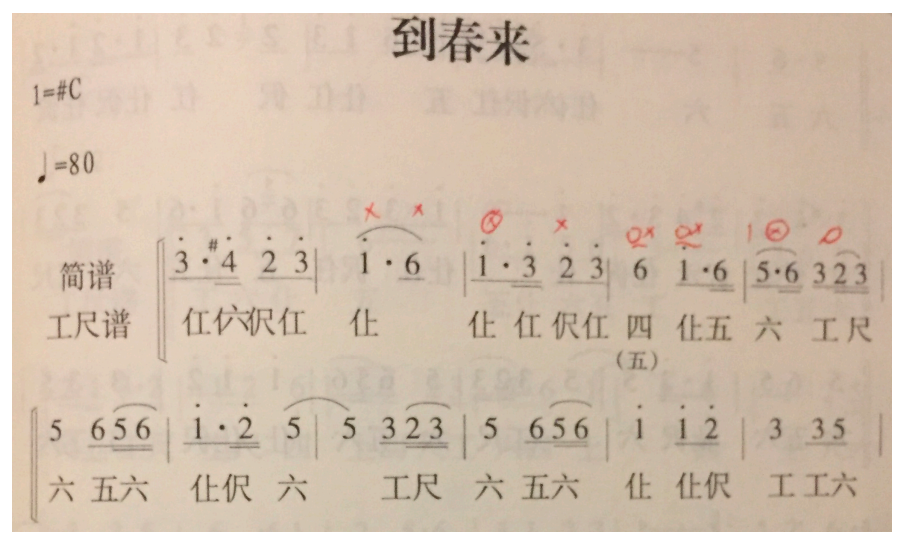

Figure 6. The corresponding spectrum of numbered musical notation and Gongche notation. The photo was taken by the author in 2020.

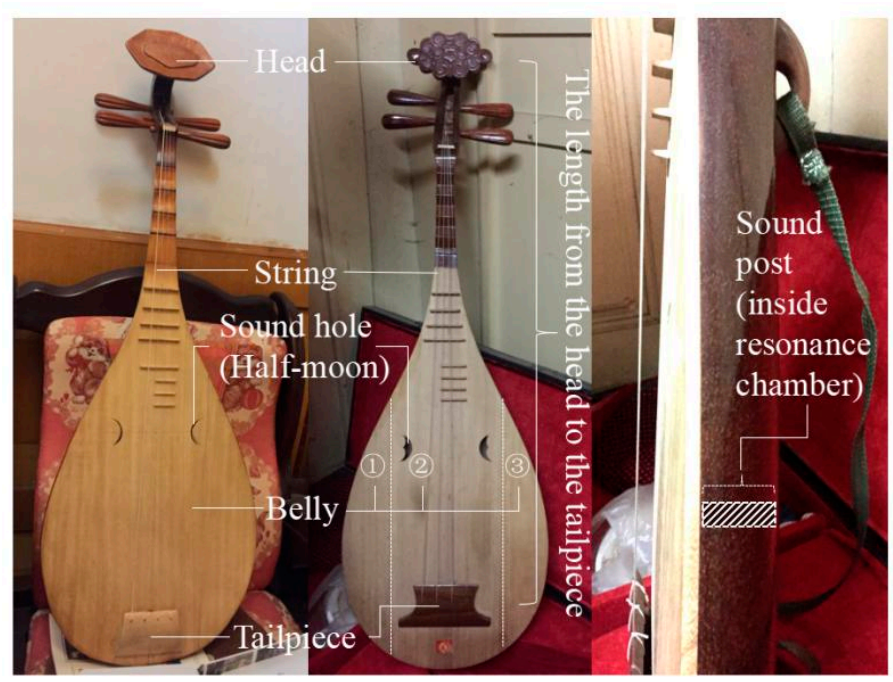

Figure 7. Pipa (the left one is a former pipa; the middle and right ones are new pipas.). The photo was taken by the author in 2020 . 


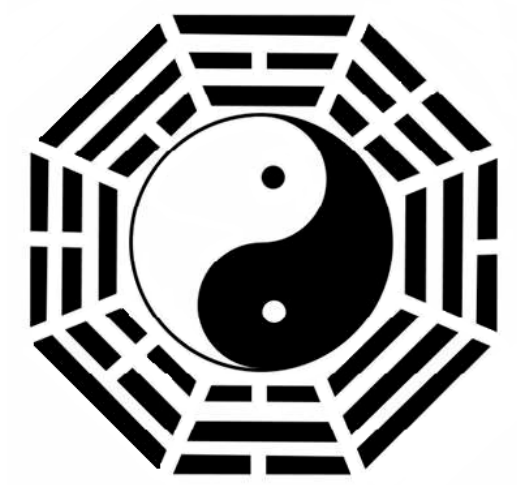

Figure 8. The Eight Diagrams of Taoism.

In summary, during the postmirror stage, the Naxi musicians still insisted on playing Naxi music, and many tourists were impressed by their insistence that it reflect authentic Naxi culture. Although the Naxi musicians still perform for tourists, they no longer cater solely to them. In terms of performance, they pay more attention to the innovation of lyrics, notations and musical instruments to obtain a better expression of Naxi music. They have gradually established the concept of music inheritance and innovation methods, and these methods are shared. According to Castells' theory, the Naxi musicians have gradually established a new project identity. Therefore, it can pass the authentication test of being "hot". In fact, the previous studies on the relationship between music and tourism show that there are two paths for local musicians: the first is that in the development of tourism, musicians should not just play music on the stage but should rather make tourists feel enthusiasm and encourage them to become part of the culture [62,63]. Second, artists must adapt to the new context and actively control their art [64]. The current study found that the Naxi musicians are similar to the latter. They not only preserve the cultural heritage in the wave of tourism development but also enrich the cultural connotation of their art form.

\section{Conclusions and Discussion}

\subsection{Conclusions}

First, through the change in the relationship between tourists and performers, we can use the mirror theory to divide the tourism development stage. Although the tourists "mirror" function has led to changes in Naxi music, which formed as a legitimizing identity in the premirror stage, it may be a positive stimulus on local music in the postmirror stage. In the premirror stage, which is before the development of tourism in Lijiang Town, Naxi music formed a series of elements that we term a legitimizing identity. In the mirror stage, which was the first twenty years of tourism development in Lijiang Town, the Naxi musicians passively catered to the preferences of tourists. This catering sometimes caused damage to the original legitimizing identity of Naxi music. In the postmirror stage, the Naxi musicians took the initiative to control the music, not only authentically inheriting the music but also actively overcoming the shortcomings of Naxi music.

Second, comparing the evaluation of the authenticity of local music from the perspectives of tourists and performers, this paper evaluates the development of local music from the perspective of insiders and outsiders over a long period. The humanist perspective is necessary to examine the authenticity of both locals and tourists. We do not emphasize the common elements identified by two groups, tourists and performers; rather, we are interested in what the two groups share. In the globalized world, legitimizing identity, resistance identity and project identity are not the final aims of the Naxi musicians themselves. The promotion of humanity is their essential aim that can be shared with other people (including tourists); that is, by both performing music and enjoying it, Cohen's concepts of "hot" and "cool" authentication were modified by this research. These aspects can be explored in other places if scholars want to evaluate changes in local cultures. We think that the research framework of this article is suitable not only for evaluating the impact of 
tourism on local culture but also for evaluating the impact of various human activities on sustainable local culture.

Third, Castells' identity theory effectively describes the transformation of Naxi musicians' emotional attitude in different stages. In Lijiang, the project identity of local musicians is clear, which is an important manifestation of cultural vitality. The Naxi musicians have found appropriate ways to make real progress in the performance of Naxi music. This research modified the concepts of "hot" and "cool" authentication and applied them to evaluate the progress of Naxi music. The "hot" authentication is shown in the expression and inheritance of the local culture by the Naxi musicians. They work to improve traditional musical knowledge and performance skills, thus forming a driving force for sharing their music with others. The "cool" authentication is shown in the mirror stage. Some Naxi musicians have lost the charm of traditional culture to cater to tourists. It is easy to lose oneself or one's project identity when people simply cater to others' tastes. Under the impact of global tourism, the Naxi musicians began to lose themselves and later reawakened. This process gives us hope for local music in the future.

\subsection{Discussion and Future Research}

The first issue to be discussed going forward is whether it is feasible to judge local culture only by the authentication of being "cool" or "hot". In this paper, we define "cool" and "hot" authentication from the perspective of mirror stage theory. This modification may be an effective extension of the concept of authentication by Cohen by which we can achieve a more humane understanding of the musicians' change of music in tourism. However, contemplating humanity's progress and freedom is a never-ending process. There are some questions that scholars have not yet answered. For example, a scholar took Lacan's psychoanalysis as a primary perspective to discuss wilderness and nature tourism in the Adirondacks of upstate New York, USA [65]. When discussing wilderness as a tourist object, he could not answer which kind of nature is more suitable for human progress. The discussion of alienation is not final. Therefore, the discussion on the authentication of "cool" and "hot" in this paper remains an open question.

The second issue that should be discussed in the future concerns who has greater authority in the determination of authenticity: tourists or local people. Through this study, we find that Lacan's mirror stage theory can reveal the changes in the relationship between the host and the guest in tourism. In an ideal condition, we might assume that the humanity of tourists and locals would be fully developed when considering tourism. However, in reality, the situation is rarely a win-win situation. The answer is better considered as whether developing should be based on the development of local people or the demand of tourists. If the number of tourists is large and the number of locals is small, it is impossible to determine who has greater authority based on the number of people. At the same time, due to the continuous development of local culture, we cannot yet assess the degree of "hot" authentication-that is, the extent to which tourism having a positive impact on local culture can be considered to be "hot" authentication.

In practice, we can learn the possible development stages for similar tourism destinations through case studies. Therefore, the results of this paper would be helpful to handle the relationship between music protection and tourism development. Innovation is an important way to realize the sustainable development of culture. In terms of how to define innovation, it is not reflected in the transformation of culture; rather, the deeper driving force is that musicians establish a project identity of music development on the basis of understanding music. Musicians not only adapt to the development of the times but also enrich the artistic charm of music. We cannot ignore that the open cultural system can provide more possible paths for the innovation of local musicians [33]. The conclusion of this study is applicable not only to Naxi music but also to the evaluation of other similar performing tourism projects. 
Author Contributions: Investigation, D.L.; methodology, S.Z.; writing—original draft, D.L.; writingreview and editing, S.Z. All authors have read and agreed to the published version of the manuscript.

Funding: National Natural Science Foundation of China: 41771148.

Institutional Review Board Statement: Not applicable.

Informed Consent Statement: Informed consent was obtained from all subjects involved in the study.

Data Availability Statement: Not applicable.

Acknowledgments: We would like to thank Gary Sigley and Stanley D. Brunn for their comments on our draft paper. Additionally, we owe many excellent suggestions for revision to the associate editor and the anonymous reviewers in helping us improve the manuscript.

Conflicts of Interest: The authors declare no conflict of interest.

\section{References}

1. Airey, D.; Chong, K. National policy-makers for tourism in china. Ann. Tour. Res. 2010, 37, 295-314. [CrossRef]

2. Szromek, A.R.; Kruczek, Z.; Walas, B. The Attitude of tourist destination residents towards the effects of overtourism-Kraków case study. Sustainability 2019, 12, 228. [CrossRef]

3. Yang, J.; Ryan, C.; Zhang, L. Social conflict in communities impacted by tourism. Tour. Manag. 2013, 35, 82-93. [CrossRef]

4. Greenwood, D.J. Tourism as an agent of change. Ann. Tour. Res. 1976, 3, 128-142. [CrossRef]

5. Squire, S.J. Literary tourism and sustainable tourism: Promoting 'Anne of Green Gables' in Prince Edward Island. J. Sustain. Tour. 1996, 4, 119-134. [CrossRef]

6. Cohen, E. Authenticity, equity and sustainability in tourism. J. Sustain. Tour. 2002, 10, 267-276. [CrossRef]

7. Su, J. Managing intangible cultural heritage in the context of tourism: Chinese officials' perspectives. J. Tour. Cult. Chang. 2019, 18, 164-186. [CrossRef]

8. Zhang, G.; Chen, X.; Law, R.; Zhang, M. Sustainability of heritage tourism: A structural perspective from cultural identity and consumption intention. Sustainability 2020, 12, 9199. [CrossRef]

9. Su, X.; Wang, H.; Wen, T. Profit, responsibility, and the moral economy of tourism. Ann. Tour. Res. 2013, 43, 231-250. [CrossRef]

10. Song, X.; Cheong, K.-C.; Wang, Q.; Li, Y. Developmental sustainability through heritage preservation: Two chinese case studies. Sustainability 2020, 12, 3705. [CrossRef]

11. UNESCO. UNESCO World Heritage and Sustainable Tourism Programme. Available online: https://whc.unesco.org/uploads / activities/documents / activity-669-7.pdf (accessed on 8 October 2020).

12. Rickly, J.M.; Vidon, E.S.; Knudsen, D.C. Irreconcilable differences: Divorcing ethics from existential authenticity. Ann. Tour. Res. 2021, 88, 103174. [CrossRef]

13. Wang, N. Rethinking authenticity in tourism experience. Ann. Tour. Res. 1999, 26, 349-370. [CrossRef]

14. Chhabra, D. Authenticity and the authentication of heritage: Dialogical perceptiveness. J. Heritage Tour. 2019, 14, 389-395. [CrossRef]

15. Jiménez-Barreto, J.; Rubio, N.; Campo, S. Destination brand authenticity: What an experiential simulacrum! A multigroup analysis of its antecedents and outcomes through official online platforms. Tour. Manag. 2020, 77, 104022. [CrossRef]

16. Naoi, T. Visitors' evaluation of a historical district: The roles of authenticity and manipulation. Tour. Hosp. Res. 2004, 5, 45-63. [CrossRef]

17. Boniface, P. Tourism Culture. Ann. Tour. Res. 1998, 25, 748-750. [CrossRef]

18. Lin, Y.C.; Liu, Y.C. Deconstructing the internal structure of perceived authenticity for heritage tourism. J. Sustain. Tour. 2018, 26, 2134-2152. [CrossRef]

19. Wu, H.-C.; Cheng, C.-C.; Ai, C.-H.; Wu, T.-P. Fast-disappearing destinations: The relationships among experiential authenticity, last-chance attachment and experiential relationship quality. J. Sustain. Tour. 2020, 28, 956-977. [CrossRef]

20. Choi, S.-H.; Imon, S.S.; Couto, U. Negotiating with Authenticity to Ensure Sustainability of Traditional Cultural Festivals: Residents' Perspectives about Macao's Drunken Dragon Festival. Sustainabilty 2020, 12, 885. [CrossRef]

21. Su, X.; Sigley, G.; Song, C. Relational Authenticity and Reconstructed Heritage Space: A Balance of Heritage Preservation, Tourism, and Urban Renewal in Luoyang Silk Road Dingding Gate. Sustainability 2020, 12, 5830. [CrossRef]

22. Io, M.-U. Collaboration between practitioners and public agencies in preserving and promoting musical heritage in Macao. J. Heritage Tour. 2018, 14, 19-32. [CrossRef]

23. Zhu, Y. Performing heritage: Rethinking authenticity in tourism. Ann. Tour. Res. 2012, 39, 1495-1513. [CrossRef]

24. Kim, S.; Whitford, M.; Arcodia, C. Development of intangible cultural heritage as a sustainable tourism resource: The intangible cultural heritage practitioners' perspectives. J. Heritage Tour. 2019, 14, 422-435. [CrossRef]

25. Butler, R. The concept of a tourist area cycle of evolution: Implications for management of resources. Can. Geogr. 1980, 24, 5-12. [CrossRef]

26. Cole, S. Information and Empowerment: The keys to achieving sustainable tourism. J. Sustain. Tour. 2006, 14, 629-644. [CrossRef]

27. Farrelly, F.; Kock, F.; Josiassen, A. Cultural heritage authenticity: A producer view. Ann. Tour. Res. 2019, 79, 102770. [CrossRef]

28. Su, J. Conceptualising the subjective authenticity of intangible cultural heritage. Int. J. Heritage Stud. 2018, 24, 919-937. [CrossRef]

29. MacCannell, D. Staged authenticity: Arrangements of social space in tourist settings. Am. J. Sociol. 1973, 79, 589-603. [CrossRef]

30. Cohen, E. Authenticity and commoditization in tourism. Ann. Tour. Res. 1988, 15, 371-386. [CrossRef] 
31. Steiner, C.J.; Reisinger, Y. Understanding existential authenticity. Ann. Tour. Res. 2006, 33, 299-318. [CrossRef]

32. Santoro, A.; Venturi, M.; Agnoletti, M. Agricultural Heritage Systems and Landscape Perception among Tourists. The Case of Lamole, Chianti (Italy). Sustainability 2020, 12, 3509. [CrossRef]

33. Canavan, B.; McCamley, C. Negotiating authenticity: Three modernities. Ann. Tour. Res. 2021, 88, 103185. [CrossRef]

34. Cohen, S.A.; Cohen, E. New directions in the sociology of tourism. Curr. Issues Tour. 2017, 22, 153-172. [CrossRef]

35. Khanom, S.; Moyle, B.; Scott, N.; Kennelly, M. Host-guest authentication of intangible cultural heritage: A literature review and conceptual model. J. Heritage Tour. 2019, 14, 396-408. [CrossRef]

36. Musa, G.; Kayat, K.; Thirumoorthi, T. The experiential aspect of rural home-stay among Chinese and Malay students using diary method. Tour. Hosp. Res. 2010, 10, 25-41. [CrossRef]

37. Matatolu, I. A critical examination of indigenous people, tourism and quality of life. J. Heritage Tour. 2019, 15, 267-278. [CrossRef]

38. Maoz, D. The mutual gaze. Ann. Tour. Res. 2006, 33, 221-239. [CrossRef]

39. Homer, S. Jacques Lacan; Routledge: New York, NY, USA, 2005; p. 25.

40. Bailly, L. Lacan: A Beginner's Guide; Oneworld Publications: Oxford, UK, 2009; p. 90.

41. Lynch, R.A. The Alienating Mirror: Toward a Hegelian Critique of Lacan on Ego-Formation. Hum. Stud. 2008, 31, 209-221. [CrossRef]

42. Goncalves, J. Is Lacan's theory of the mirror stage still valid? Psychol. Res. 2012, 2, 431-440. [CrossRef]

43. Brown, L. Tourism: A catalyst for existential authenticity. Ann. Tour. Res. 2013, 40, 176-190. [CrossRef]

44. Gillett, G. Signification and the unconscious. Philos. Psychol. 2001, 14, 477-498. [CrossRef]

45. Sheriff, R.E.; Mageo, J. Young Americans' Dreaming in the Specular Age. Ethos 2019, 47, 129-147. [CrossRef]

46. Cohen, E.; Cohen, S.A. Authentication: Hot and cool. Ann. Tour. Res. 2012, 39, 1295-1314. [CrossRef]

47. Ryan, C. Maori and Tourism: A Relationship of History, Constitutions and Rites. J. Sustain. Tour. 1997, 5, 257-278. [CrossRef]

48. Xu, H.; Wan, X.; Fan, X. Rethinking authenticity in the implementation of China's heritage conservation: The case of Hongcun Village. Tour. Geogr. 2014, 16, 799-811. [CrossRef]

49. Chhabra, D.; Healy, R.; Sills, E. Staged authenticity and heritage tourism. Ann. Tour. Res. 2003, 30, 702-719. [CrossRef]

50. Mkono, M. Hot and cool authentication: A netnographic illustration. Ann. Tour. Res. 2013, 41, 215-218. [CrossRef]

51. Knudsen, D.C.; Rickly, J.M.; Vidon, E.S. The fantasy of authenticity: Touring with Lacan. Ann. Tour. Res. 2016, 58, 33-45. [CrossRef]

52. Wijngaarden, V. Tourists' agency versus the circle of representation. Ann. Tour. Res. 2016, 60, 139-153. [CrossRef]

53. Giddens, A. Modernity and Self-Identity: Self and Society in the Late Modern Age; Polity Press: Cambridge, UK, 1991.

54. Castells, M. The Power of Identity; Blackwell: Oxford, UK, 1997.

55. Etzioni, A. The Spirit of Community: Rights, Responsibilities, and the Communitarian Agenda; Crown: New York, NY, USA, 1993 ; p. 15.

56. Baumeister, R.F.; Muraven, M. Identity as adaptation to social, cultural, and historical context. J. Adolesc. 1996, 19, 405-416. [CrossRef] [PubMed]

57. Revill, G. Music and the Politics of Sound: Nationalism, Citizenship, and Auditory Space. Environ. Plan D Soc. Space 2000, 18, 597-613. [CrossRef]

58. Wood, N.; Duffy, M.; Smith, S.J. The Art of Doing (Geographies of) Music. Environ. Plan D Soc. Space 2007, 25, 867-889. [CrossRef]

59. Wood, N. Playing with 'Scottishness': Musical performance, non-representational thinking and the 'doings' of national identity. Cult. Geogr. 2012, 19, 195-215. [CrossRef]

60. Wu, X.Y. What is "Naxi Ancient Music"? Arts Criti. 2003, 1, 5-13.

61. Tian, Q. Adjudge without justness. Arts Criti. 2005, 3, 5-13.

62. Fry, R.W. Becoming a "True Blues Fan": Blues tourism and performances of the King Biscuit Blues Festival. Tour. Stud. 2013, 14, 66-85. [CrossRef]

63. Spracklen, K.; Spracklen, B. The strange and spooky battle over bats and black dresses: The commodification of Whitby Goth Weekend and the loss of a subculture. Tour. Stud. 2013, 14, 86-102. [CrossRef]

64. Kaul, A. Music on the edge: Busking at the Cliffs of Moher and the commodification of a musical landscape. Tour. Stud. 2013, 14, 30-47. [CrossRef]

65. Vidon, E.S. Why wilderness? Alienation, authenticity, and nature. Tour. Stud. 2017, 19, 3-22. [CrossRef] 